\title{
Qualitative Research and Narrative Sources in the Context of Critical and Renal Cares
}

\author{
José Siles-González, Carmen Solano-Ruiz \\ Nursing Department, University of Alicante, Alicante, Spain \\ Email: Jose.siles@ua.es, Carmen.solano@ua.es
}

Received 17 February 2014; revised 12 April 2014; accepted 7 May 2014

Copyright (C) 2014 by authors and Scientific Research Publishing Inc.

This work is licensed under the Creative Commons Attribution International License (CC BY). http://creativecommons.org/licenses/by/4.0/

(c) (i) 0 pen Access

\section{Abstract}

The objective of this study is to clarify the relevance of qualitative research in the context of critical care and renal dialysis requires using narrative sources. Also specific objectives are to identify the phases or cultural moments that are distinguished in these processes. Research Question: How can the narrative materials contribute to the study of the processes of critical care and/or qualitative research in nephrology? Method and Sources: There have been studies focusing on the narrative of patients who have written their experiences building a literature experience ill (Siles et al., 1997, 1999, 2000). Sources have been used to extract testimony retrospective autobiographies written by people who have experienced the experiences of different diseases (Allué, 1996, 1997, Zorn, 1991, Gilbert, 1993; Comas, 2009; Gracia Armendáriz, 2010; Sampedro, 1996, Sacks, 2010). The analysis was developed by categorizing units of meaning, meaning families and networks. To identify the cultural moments we have followed the criteria established by Siles and Solano (2009): Multiculturalism, interculturalism and transculturalism. To identify rites of passage and liminality states have followed the principles outlined by Van Gennep $(2013)$ and Turner $(1990,2008)$. Results: We identified cultural moments and characteristic states of liminality in critical care and kidney. Conclusions: narrative sources are effective for analyzing the meanings and experiences of patients in critical care and nephrology tool.

\section{Keywords}

Nursing, Narrative Anthropology of Care, Qualitative Research, Critical and Renal Cares

\section{Introduction}

Patients who live in the critical care unit and/or nephrology undergo a series of experiences that influence the way to tackle the disease and also influence their social, family and professional environment. The need to un- 
derstand and describe the experiences of patients in critical care and/or nephrology is the first step for the professional care through reflection, and to find the corollary of meaning derived from such experiences. Through qualitative research in critical care and/or nephrology can come to understand and describe the experiences of patients and the meanings of the same, which is, first, an effective tool to adapt care to the "sensitivities" and personal, social and family characteristics of the patients, and, moreover, strengthens the vision and practice of humanism in care.

\subsection{Objectives}

-Clarify the relevance of qualitative research in the context of critical care and nephrology as a facilitator of the process of understanding, description and explanation of meanings involved in such care.

-Reflect on the appropriateness of the narrative materials in qualitative research.

-Identify cultural phases or moments that critical processes are distinguished and renal diseases requiring hemodialysis.

-Describe the situations of liminality that occur in the transition process health and disease.

\subsection{Research Questions:}

In what ways can the narrative materials contribute to the study of the processes of critical care and/or qualitative research in nephrology?

What cultural moments or phases can be identified in critical processes and renal diseases requiring hemodialysis?

\section{State of the Question on Qualitative Research in Critical and Renal Cares}

The variety of conceptual contributions that attempt to clarify the nature and scientific characteristics of qualitative research context and exceeds the limits of this study, but may give you some examples: interdisciplinary field, disciplinary and, in many cases, contradisciplinar. It crosses the humanities, social sciences and physica [1] [2]. Taylor and Bogdan [3] identified qualitative research as that which produces descriptive data: people's own words, spoken or written and observable behavior. Goetz and LeCompte [4] state that qualitative research has some essential features that can be summarized in the following points: a form of reality by inquiring descriptions from observations that take different forms (interviews, narratives, field notes, recordings, transcripts of audio, video, written records of all kinds, photographs, films, artifacts, etc.). Qualitative research involves a process in which data are presented in complex ways, as they really are, and to sort the researcher makes use of hermeneutics, understanding, sense through the experiences and subjective world. In this sense Szent-Györgyi [5] states: "If I go to nature, to the unknown, to the outskirts of knowledge, everything seems confusing and contradictory, illogical and incoherent. This is what makes qualitative research: lima contradiction and becomes simple, logical things". But qualitative research is not homogeneous, but its theoretical and methodological approaches depend on the starting paradigm: from the hermeneutic or interpretive paradigm and from the sociocritical paradigm, as the objective of either descriptive study of understanding and interpretation (hermeneutics), or, beyond that, the involvement and participation of the person and their environment (family, social, work) in solving their problems (sociocritical) [6]. In the second case, to encourage the participation of the individual and their environment, ideological stance based on democracy, freedom and awareness of the individual and the environment of the problem in question is adopted [7]. Ultimately, transdisciplinarity constitutes a challenge because in the conceptual richness of perspective and theoretical and methodological adoptions, the investigator must demonstrate their ability to work in research whose boundaries constitute genuine crossroads. It is what some authors denominate methodological and theoretical pertinence in qualitative research [8] [9]. It could carry a synthetic description of the characteristics of qualitative studies defining these as: Investigation of a particular phenomenon, conducted in depth and in a holistic manner through collecting narrative information and using a design flexible and transdisciplinary research.

Both critical and nephrological cares, can cause considerable disruption of perceptual capabilities that affect the patient-provider relationship, mainly in the processes of interaction and communication. Critical relationship between health problems and perception studied by Oliver Sacks from different perspectives in works such as: An Anthropologist on Mars, The Man Who Mistook His Wife for a Hat, and Musicophilia [10]-[12] (Sacks, 2004, 2006,2009 ) or problems chronic diseases and sensory and perceptual disturbances. Sacks does not waive reflect 
on the phenomena of the mind from the complexity of it. This perspective allows you to discover the sensory and perceptual uncertainty in people who respond to your problems by building new existential landscapes in which experiences change color, shape, sound, touch, smell, etc.

In this context of the perceptual Maurice Merleauy Ponty fails to recognize that the body itself is more than one thing, something more than an object to be studied by science, since it is mainly a permanent form and necessary for the existence and opening interaction with reality through perceptions, but this perceptual openness involves more than relationship with reality, as constructed realities arising from the interpretation of perceptions. Consequently, the primacy of perception means the primacy of experience to the extent that perception has an active and constitutive dimension, for example, without perception of the health problem, there is no health problem and therefore there is no awareness Merleau Ponty himself [13].

Qualitative studies have been conducted in which the experiences of relatives of patients admitted in the intensive care unit [14] [17] are described. A considerable part of these experiences is the perception that family members have the critical patient. Uribe Muñoz and Restrepo [18] conducted a study analyzing the family perception of critically ill patients, especially their wives, considering the feelings and the impact on them of factors such as age, religion, morals, values, number of children, etc. Other authors emphasize the participation of patients [19]. Other studies focus on family care of critically ill patients [20], which, somehow, is a form of participation by the proximity of the care recipient. This involvement of families in the care of critically ill patients opens the way to studies in which the aim is to assess the needs of relatives in such complicated circumstances [15] [16] [21]-[24]; as a determining factor in a global context of professional-family interaction characterized by both the precariousness of professional training for such cases, and the difficulties arising from the situations (stressors themselves both for families and professionals). There are some researches that relate the stress experienced by families with critical with the emergence of anxiety problems and even depression patients [25].

\section{Sources and Methods}

Qualitative methodology focuses its focus on the opinion of the investigated biographical narrative [26]. In this sense Saltalamacchia [27] is expressed when endorses casuistry and subjectivism as two pillars of qualitative research that have been stigmatized by appealing to their unscientific character. The involvement of patients and families in the biographical narrative is essential to reinterpret reality in the light of new conditions of life that require adaptation efforts by both patients and family members. The narrative sources facilitate the study of the experiences of critical or chronic care in the time of receiving the diagnosis involves a radical change in the perception of the individual about himself and everything around him (family, work, leisure) [28]. In short, as Bruner [29] notes the biographical narrative facilitates the construction of new realities from the subjectivism of the subjects involved. There have been studies focusing on the narrative of patients who have written their experiences building a literature experience ill [30] [31] [32]. Several authors have addressed systematically the nature of narrative methods in the context of the experiences of patients [33]-[37]. Frank [38]-[40] (1995, 2001, 2002), meanwhile, profound questions (investigator suffering, the pain of the narrator and the dialogical ethics of narrative analysis processes) in qualitative research based on narrative accounts raises its various forms. Sources are considered suitable for this type of retrospective studies testimonials autobiographies written by the very people who have experienced the experiences of different diseases [41]-[48] account for the sense of isolation and the importance of the attitude of the professionals as the first step of that escape confinement: dialogues, nonverbal expression, touch, in short, some interaction sensory and emotional denoting a deal from person to person with a clear determination to enable some form of communication.

To identify cultural moments have followed the criteria established by Siles and Solano [49]. Also, to describe bonding and the parallels between the cultural moments and rites of passage or transition states of liminality and have followed the principles outlined by Van Gennep [50] and Turner [51] [52].

A qualitative design was used to study the liminal experiences of people with critical care and chronic renal disease. Constructivist perspective [53] was adopted because it is assumed that indi-viduals, groups and cultures create interpretations of realities and develop them through the stories they tell. Accepting that experience happens narratively [34], the stories narrated allow studying how people understand and make sense of what happens [54]. Connelly and Clandinin (2006) identified the three essential components of narrative inquiry: temporality, sociality, and the stage [37]. 


\section{Results and Discussion}

Relevance of qualitative research in the context of critical care and nephrology as a facilitator of the process of understanding, description and explanation of meaning: holism, complexity, mainstreaming person. The holism (derived from holos: all, entire, total) on the principle that all properties of a given system (biological, chemical, social, economic, mental, cultural) can not be determined by the component parts by alone, i.e., the system-like "holos" whole-affects the behavior of the various component parts. Holism is summarized in the phrase "The whole is more than the sum of its parts", Aristotle coined in his "Metaphysics". When a system such as the human body is in a state of disease, determination or subject to certain limitations by it, the body, as holos, remains a disease that transcends all. Whereas the person is more than body art and it encompasses, it is logical that patients want to continue to be treated as people without the disease to become exclusively to surround the attention of health professionals. This may seem obvious, but as said Hurley [55] and Barthes [56], the obvious, too often, is as invisible as evident, leading to biased or obtuse interpretations of reality. Some autobiographical testimonies of kidney patients and critical care, describe situations in which, too often, they have to assert themselves as individuals and not just as a disease [57]. That is, in the stories described how patients in critical care units or hemodialysis machine steals limelight from the person while the nurse focuses on the machine. In the case of critical care due mainly to the deficit or apparent loss of perceptual abilities of patients, in the case of hemodialysis units to the need to care as much or more purifying machine (temporary repository of the soul or blood patient and, therefore, of his person). In both cases, patients expressed their need for care as. It also happens in something like Awakenings, where patients express stop being afraid to let its people awake state and return to a dormant irreversible [58]. Narrative inquiry is particularly suitable for the study of the experiences of disease where a diagnosis is often experienced as an interruption of one's life/story.

Personality: Etymologically, the term personality from the Greek "prosopon" (mask used by actors in the act of representing theatrical characters). Personality is, in that sense, what is perceived, what others are able to distinguish by observing each individual. The Latin etymology of the word "personare" (which resonates through) also refers to the way others perceive individuals. For authors like Gombrowicz [59], personality is the dialectical resulting from the need for social adaptation and the need to overcome the effect of such an adaptation that causes choking in absolute terms. Sontag [60] talks about the difficulty of speaking openly about cancer diseases (without rhetoric or the use of metaphors). These resources function as euphemisms and masks that keep the individual and those around him out of a reality shaped by the disease. The first types of personality we owe to the time of ancient Greece, as in this great compilation of the era is the "Corpus Hipocraticum" four varieties of personality that are related to the four elements (air, earth, fire, water) that formed the Cosmos. Hippocrates claimed that the microcosm of man was composed of these four elements transformed into moods and that the preponderance of any of them was as stumps types and other mood. The concept of person part of the consideration of the structural nature of it. The person considering this structure is as structurally character as an orderly whole according to their purposes and functions. Lain Entralgo gives the person is structural, since it is a unitary whole set, also executor of unit activities, including that of living as an individual [61]. The structure is the foundation unifying and holding points that walls, ceilings and other elements on which a building stands are located. The staff structure is a system that keeps a consistent and functional two primary subsystems: the psychological and organic. On the other hand, involves individuality human outstanding feature. Allport argues from a humanistic interpretation of social science that individuality is manifested in everyday life and on the social level when establishing relationships. In short, for Allport, individuality is the essential characteristic of human nature, while personality is "the only dynamic organization of psychophysical systems that determine a way of thinking and acting, in each subject in the process of adaptation environment" [62]. Other authors such as Huxley said that personality depends on three factors: heredity, circumstances and freedom. The only personality and individually manifested by perceptual capacity inherent to every human being: body awareness through the senses, historical memory, individual and collective consciousness, and so on. From other paradigms, such as the neo-positivist, he studied science from reductionist perspectives fragmenting the human being as a person and subject of research by reducing him to a mere object of study. The structural framework of the person is founded on a cultural basis on which four stand incidental spheres: law, religion, ethics and political system. These four spheres orbit and shape the circle in which different areas of personality develop: awareness of one's experience, myths, traditions and morals (Figure 1). In written sources autobiographical form, the authors reflect the relationship between your body and awareness by the same person. 


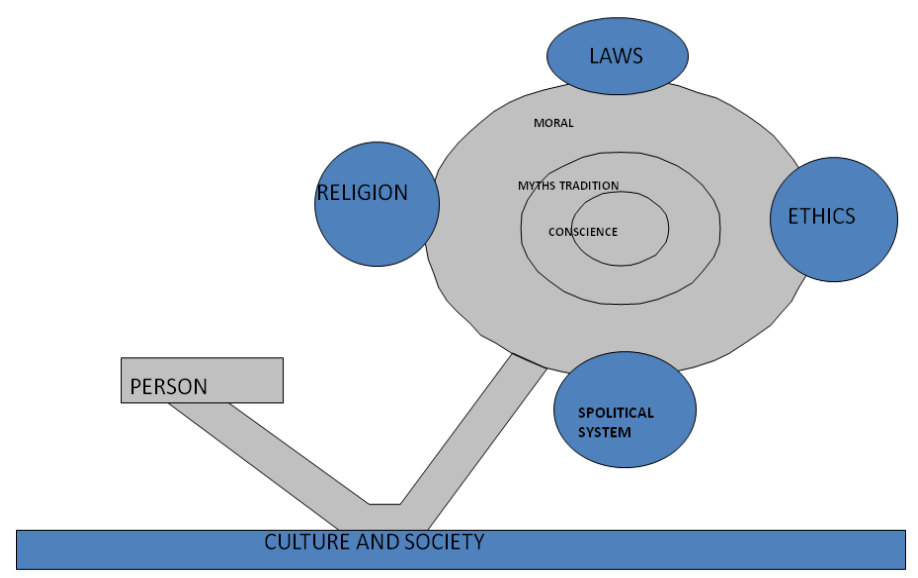

Figure 1. Structural framework of person. Source: Siles, J. \& Solano, M ${ }^{a}$ C. (2009) [49] Siles, J. \& Solano, C. (ed.) (2009) Antropología educativa de los cuidados. Una etnografía del aula y las prácticas clínicas. ICE. Universidad de Alicante, Alcoy, Alicante. Disponible en: http://rua.ua.es/dspace/handle/10045/20339.

It is a dynamic process of awareness as the body changes and new situations that will require re-interpretation processes of the body itself produce.

Temporality, sociality and scenarios:

Some examples of these meanings culled from the narratives are exemplified by Barthes (1986: 18) both the "ICU" and hemodialysis services: "(...) is the very pose of the character which leads to the reading of the meanings of connotation" [56] (Barthes, 1986: 18). They are situations where time takes on a totally different from everyday life dimension. Or not perceived (in the case of critical care in the ICU, or perceived in a distorted way in hemodialysis units sociability and personal interaction is limited to just touch sensation experienced by the patient to the technique that is being applied by the nurse. sometimes has totally altered or canceled their perceptual abilities, and their sociability is limited to the potential perceptual problem is that on many occasions the nurse knows the perceptual reality of his patient is a person who hears or feels as if I did (these situations are especially frustrating for patients in the ICU).

Scenarios have a great impact on the mood and perception of patients. In critical care or hemodialysis units are recharged the technology scenarios in which people appear prostrate, dependent, incommunicado (apparently at least), exiled from his family, cultural and plunged into a unifying environment on uniformity that objects have a pose that also invites interpret meanings that are part of this unifying homogeneity, since the item monitors where the constants of the people are green (go out of his body and exhibited in the object), oxygen masks that restrict vision partially hiding his face, hemodialysis machines to "walk" from the patient's blood inside your body to the "cleaner object" and, once the miracle wrought purification, the return again to be for it to continue. Of those felt by the patient before hemodialysis Gracia Armendáriz speaks connotations in his "Diary of a pale man": In this sense expresses Gracia Armendáriz [47]: "But sooner or later the day comes when the patient enters the circuit therapy, on the assumption of a routine in which you must get used to the scandal of the blood and fantaciencia of their vital fluids away from your body to circulate for four hours between the membranes and salt solutions of Machine". (Gracia Armendáriz, 2010:143). The analyzed materials present narrative situations transversely without sacrificing complexity. Describes ideas, facts, feelings, values, beliefs, etc. In all sources, which are linked to the process that is living. Based on the principles of holism in anthropology and complexity developed by Morin [63], Siles, Solano and Cibanal [8] point out the complexity anthropology seeks to address the fragmented and reductionist approaches to science, through a synthesis methodological, epistemological and bilogical. The human being is a complex system, therefore different types of subsystems that integrate biological, social, psychological, cultural, and the difficulty to analyze each of these subsystems from a holistic level.

\subsection{Paradigms and Cultural Moments in Critical and Renal Cares}

Paradigms are conceptual and methodological platforms consensus. Kuhn was the one who adapted the term 
from linguistics to science. For Kuhn paradigms serve, first, to identify the different disciplines have to investigate problems and, second, it is useful to guide scientists in adopting the theories, methods and techniques that have to adopt consistent and solid, what Siles called "methodological relevance" becomes a metaphor between poetry and research, as in any research process, the verses have to rhyme in assonance and consonant, what comes to signify the importance of epistemologically clarify both the nature of the research problem to know how to locate the paradigm with the theories, methods and techniques consistently for the research work do not waste your routine.

\subsubsection{Hermeneutics}

From this paradigm, which exceeds the purely technological level neopositivista-rational paradigm the research process is conceived as a subjective interval (both by the researcher subject and object-subject investigation). Theoretical knowledge is the result of the interaction that takes effect in practice of the given discipline (nursing, education, procedure). Since the approaches of this paradigm a nurse is considered a communicator and interpreter of reality of the patient agent. The characteristics of the interpretive paradigm within nursing have been studied by several authors [6] [9] [64]. To facilitate understand ding of the situations of critical care and nephrology type studies are performed mainly descriptive that analyze the meanings of the situations experienced by patients, families and professionals. Consequently, patients and their families have a voice, are listened to and what they say is collected through qualitative techniques such as life history, life stories, in-depth interviews, semi-structured, case studies, field notes, participant observation and nonparticipating narrative materials ranging from the story to the autobiographical novel in which life experiences are recounted, etc.. In short, paradigm, these approaches provide qualitative research in which people are cared for in critical care nephrology and they continue to be treated as such and not exclusively as carriers of disease. Although it is obvious that are more than a disease, too often they are treated as if they were locked in a category that eats them the status of a person leaving a look of pure disease is the absorbed the attention of professionals.

The sources consulted narratives share the characteristics of hermeneutics. The individual plays himself translating his experiences in a text which will then, in turn, to be interpreted by others. The transmission of knowledge, facts, beliefs, values, feelings that occurs by reading and inter-pretation of the autobiographical text facilitates another-distant geographical, cultural or temporarily-identifying the meanings experienced by the author.

\subsubsection{Sociocritical Paradigm}

The critical paradigm is characterized by the dialectical-critical nature of the process knowledge and taking into account the important role of ideology in the scientific process. The function and fundamental purpose of the budgets this platform are participatory emancipation and activities and tasks in the processes that occur in practice and are socially significant. The practice is critical and collaborative action. Habermas is the researcher who has contributed most to the development of critical paradigm.

The nurse is considered as an agent of socio change [6] [9]. One way to spray the isolation of patients by opening the living space critically their disease situations parallel facilitating any possible way of communication with the outside, the visits are their familiar social and professional network. Several studies have described the family visits as a tool to re-humanize the closed clinical context and also explain its benefits, but also, of course, the drawbacks that can lead [65]-[67]. For some authors, this insulation breakdown and isolation is a benefit not only for ethical reasons or humanists, but also for its worth as a positive influence on prognosis [68]. Also be considered as a relevant factor in this process of participatory involvement of the patient environment, the views and beliefs of professionals on the impact of visitors [68].

Qualitative methodology should focus on the opinion of the investigated biographical narrative [26]. In this sense Saltalamacchia [27] is expressed when endorses casuistry and subjectivism as two pillars of qualitative research that have been stigmatized by appealing to their unscientific character. The involvement of patients and families in the biographical narrative is essential to re-interpret reality in the light of new conditions of life that require adaptation efforts by both patients and relatives. In short, as Bruner [26] notes the biographical narrative facilitates the construction of new realities from the subjectivism of the subjects involved.

Participation in solving the problems is a form of freedom of the person as such and also the free-dom of his family, social and work environment [7] (López Parra, 2001) and, also, this position can only raise from ideological democratic and participatory schemes in which the person maintains at all times the condition is inherent 
in the mature and responsible citizen lifestyles. Freedom is not easy to take on and involves taking a compromising position with life. Is only true when it is conscious of its destiny, its mission, its fundamental questions, who am I? Where did I come from? and what for where I'm going? Is faced with the enigma of Oedipus before the Sphinx, which poses a fundamental dilemma. The Sphinx, in Greek mythology, monster with the head and breasts of a woman, body of a lion and wings of a bird. Squatting on a rock, addressed to all who would enter the city of Thebes by posing the following riddle: "What has four legs in the morning, two at noon and three at night ?" If challenged not solve the riddle, she killed them. When the hero Oedipus solved answered: "Man, who crawls shortly after birth, walks on two legs as an adult, and walks with a cane when he reaches old age," the Sphinx committed suicide [7] (López Parra, 2001). From this participatory perspective, the association is the highest expression of participation, since it involves groups of people who share similar problems due to a chronic process. In this sense, more associations of people with chronic diseases interactively collaborate on improving the quality of life there.

\subsection{Moments Cultural Liminality in Chronic, Critical and Renal Cares}

The changes in the different situations of health and illness experiences that cause different forms of interpretation of the phenomenon is derived. From the time of diagnosis of the disease to the patient's integration into the community of people who share with him the same problem a number of socialization processes loaded with symbolism, intercom and discoveries in the rites of passage that occur (Van Gennep, 2013, Turner, 2008) [50][52] that involve social changes. Through the transition made through rites of passage individuals leave situations of uncertainty and disorientation caused by not being part of the community of "sick" nor be part of the group and considered "healthy". Overcome situations of "liminality" (situations characterized by being authentic crossroads or limbs). The different phases are distinguished in these processes of change are called cultural moments [49]. Basically three phases which are called cultural moments and responding to different phases or sections within the situational process that occurs in all disease are distinguished. Liminality is especially true in multicultural times due to the lack of communication between the pre-diagnosis and the immediate post-diagnosis phase. The patient cannot find a way to tie these situations and reinterpret the new situation (Figure 2). Also in the transit of multiculturalism to interculturalism and transcultural situations of "liminality" characterized by the moments that have their times of uncertainty from one situation to another occur.

A) multicultural Moment (typical of the neo-positivist paradigm):

A1: From the perspective of the person who has been diagnosed with a disease, you can reply to the stage where there is a wall between lifestyle, expectations and prior to detection of the disease (Figure 2) culture. At this stage it is almost impossible reconciliation with the lifestyle required by the new situation demands produced by the new state of satisfaction of needs, or is struggling to implement compensatory mechanisms are not met. There is usually a feeling of rejection and hate for changing repudiating the new situation. In critical care the isolation is reinforced by the high technological level of critical care units. In nephrology care and periodic temporary dip keeps the patient in a position of strict dependence on the machine and that the "plug" it occurs.

A2: From the perspective of the professional-patient relationship is characterized by the lack of not strictly necessary for the performance of communication techniques and therapeutic compliance: The patient has no voice, only abides by the regulations and is subject to therapeutic procedures. This has been traditionally indoors and ICU services, but also in dialysis units and nephrology care services. In this phase all the scenery multicultural units or intensive care hemodialysis units represent anything into which the patient feels a stranger to monitors, hemodialysis ma-chines and other devices and people (professionals and other patients).

B) intercultural Moment (characteristic of hermeneutics):

B1: From the patient's perspective is a step forward, starting the process of recognition and recon-ciliation with the new state requirements. Reinterpreting the scale of values. Consequently gaps begin to occur in the wall (Figure 3) between before and after the diagnosis situation and the person talks to herself and is being recognized in the new situation, the disease until it finally comes to understand the new reality which is installed.

B2: particularly significant moments put the patient through their new reality through impact which is causing awareness of your body change as the previous fistula connected to the machine, the connection of the probe to a bag hanging on the side of bed or connecting to a monitor that unravels the secrets of her body showing them with lines undulating fluorescent green color or loud sounds. New evidence, fistula probe, connecting to a monitor, in short, show a certain state of dependence and contributes to the body's own reinterpretation of the patient 


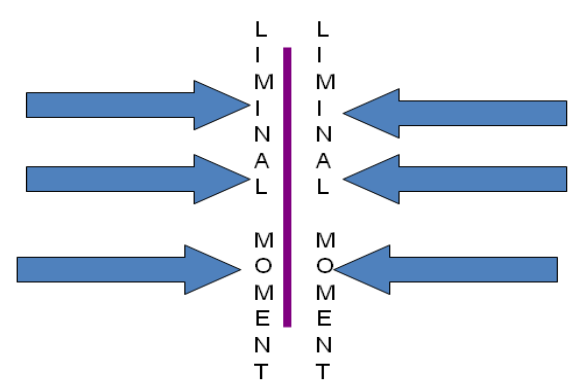

MULTICULTURALISM

\section{Situation of solitary confinement with respect to their new reality.}

(There is not a way to tie the two realities: pre and post diagnosis).

Figure 2. Cultural moments in critical and renal cares. Source: Siles, J. \& Solano, C. (ed.) (2009) Antropología educativa de los cuidados. Una etnografía del aula y las prácticas clínicas. ICE. Universidad de Alicante, Alcoy, Alicante. Disponible en.

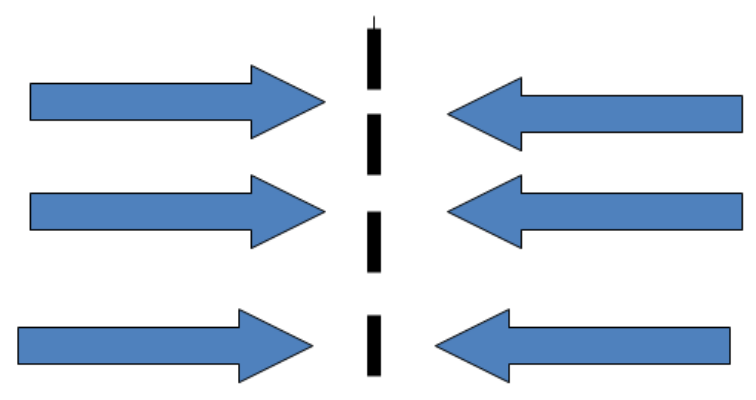

INTERCULTURALISM

\section{Communication between the two realities and understanding of the new situation}

Figure 3. Cultural moments in critical and renal cares. Source: Siles, J. \& Solano, C. (ed.) (2009) Antropología educativa de los cuidados. Una etnografía del aula y las prácticas clínicas. ICE. Universidad de Alicante, Alcoy, Alicante. Disponible en: http://rua.ua.es/dspace/handle/10045/20339.

and through that rebuilding will start the new situation. From the perspective of the patient-professional relation-ship, an interactive dialogue occurs between professional-patient resulting in more personalized care

C) Transcultural moment: (characteristic of Sociocritical paradigm)

$\mathrm{C} 1$ : From the perspective of the patient in this period the patient's awareness that assumes its involvement in the process as a key factor in their care who actively participates together with their immediate environment (family, social occurs, professional). Accept the reliance on technology and seeks to lead as independent a life as possible (Figure 4).

C2: From the perspective of the patient relationship, professional collaborative interaction that affects the practice of care in which the patient and his environment have a voice and participation develops. Professional acts as an agent of socio change.

The Tool Musicophilia How Communication with Patients in Critical Care and Nephrology How to enable some form of communication with critically ill patients when we are not sure of their perception 


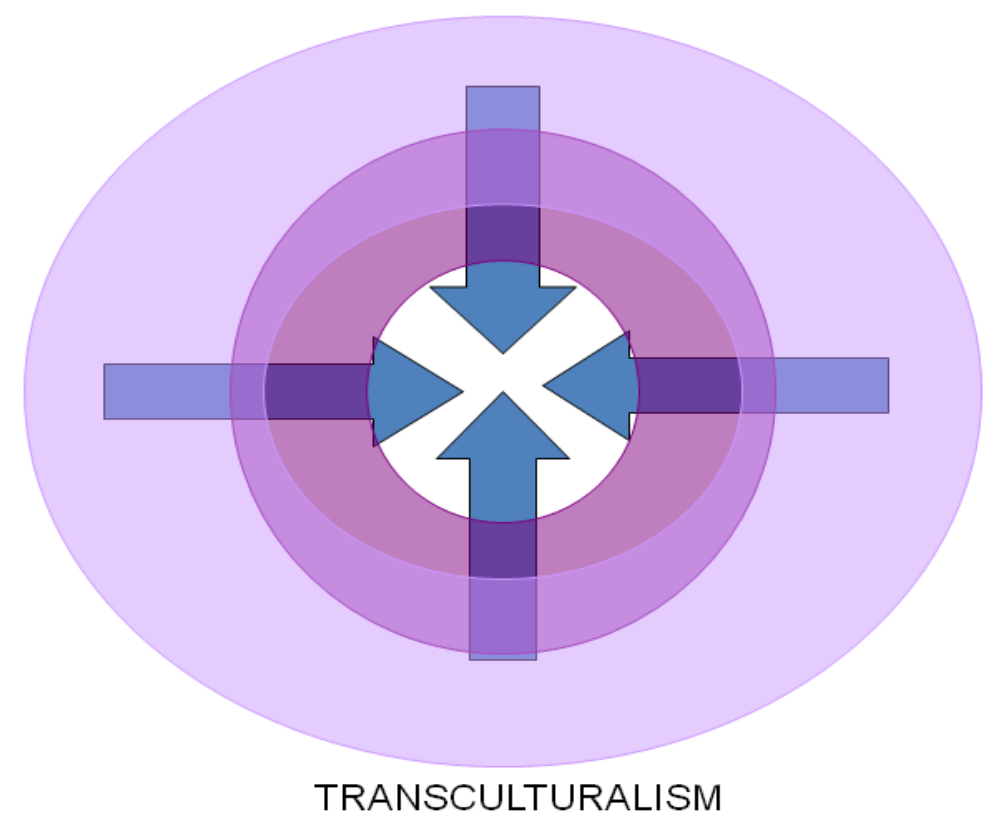

Figure 4. Cultural moments in critical and renal cares Source: Siles, J. \& Solano, C. (ed.) (2009) Antropología educative de los cuidados. Una etnografía del aula y las prácticas clínicas. ICE. Universidad de Alicante, Alcoy, Alicante. Disponible en: http://rua.ua.es/dspace/handle/10045/20339.

to level ? Several studies have shown different effects of music critics and nephrology patients. Some studies have shown the usefulness of music for local produce sedation, anesthesia [66], in dental clinic and so on. In patients who are in critical care situations, music stimulates the feelings that still occupy some space in the brain that seem to relive the emotions in patients when they hear something that has to do, or not, with previous experience: music meaningful patient [67]. Oliver Sacks describes the use of music in patients with neurological problems and their potential to reorganize their perceptual and emotional systems [12].

\subsection{The Narrative as a Source of Knowledge in Critical Care}

Narrative materials describing the experiences of people living in nephrology or critical care are a source of knowledge from the principles of the hermeneutic and socio-critical paradigm, qualitative research methods and biographical and autobiographical narrative techniques. In short, this type of sources, theories and methods relevant for:

a) The descriptive study that reflected the facts, meanings and feelings on the part of that has lived, facilitating the understanding of the phenomenon holistically.

b) Tools that can contribute to the awareness of the new realities in which people and their environments (family, social and professional) in critical care situations or are nephrology. And consequently, enhance socialization of these people and their organization in groups and associations involved in improving their living conditions.

\subsubsection{Narrative and Renal Cares}

In any chronic condition affecting the body changes occur, but also the language to what is happening. Metaphors creatively to not bottom are used, often painful issue through metaphors, especially in situations such as cancer or AIDS, but metaphors are also used to refer to hemodialysis and ICU Sontag and Conelly and Clanding [54] [60] identified the three essential components of narrative inquiry: the person and time (time being and heideggerian), sociability, and space. In his view, the understanding of the people who are in these situations, build their reinterpretations of their new realities and problems considering primarily through personal time, social conditions, and the contexts in which the experiences take place. All this is essential for the design and analysis of rigorous narrative inquiry [35]. 
Kierans and Maynooth [69] explore the experiences of patients with chronic renal failure in the final state. They use in-depth interviews (77 cases) and 12 life histories applied as a source of data collection in hemodialysis units from different cities in Ireland. They found the cultural exchange of experiences from a natural event that affects the physiology of individuals. From the daily diagnostic needs are considered just or even trivialize as eating, drinking, urinating, having sex, social or labor participation and actions are not part of a response to everyday life. Now, in the new situation of dependence on the hemodialysis machine new ratings and sensations that affect the reinterpretation of the ranking values and priorities of the patient who needs to reinvent itself with a new self-image, an image that also has cultural components arise and social impact on one or sandwiched always linked with hemodialysis family, social and work experience. After a hemodialysis patient recounts how angry he was with his family when he returned home: “(...) I could hear the bubbling. I never imagined it would be this bad experience. When the anesthetic disappeared, the pain was terrible. Mentally I found most disturbing, I thought I had reached the end (...)" [69] (Kierans and Maynooth, 2001: 244). In general prevailing feeling of dependence on the hemodialysis machine and fistula nuclear occupies a place in the experiences of patients, because depending on how it evolves, adapting to family, social and professional life is more or less.

Anita E. Molzahn, Laurene Sheilds Anne and Bruce (2008) in her work: "Learning from stories of People with chronic kidney disease", study the panorama of patients who were being treated with hemodialysis Participants in this study were those who had the history of the heroes of the book: 100 stories of experiences with renal insufficiency (DTU, 2000). All were receiving treatment in Units Dialysis and Transplantation, Royal Victoria Hospital, McGill University Health Center in Montreal. The book includes stories of 100 people (62 men and 38 women). Their ages ranged from 21 to 88 years, and cover a wide range of treatment modalities and a wide range in the length of experience with the treatments. In Canada, in 2004, 18,827 people in Canada were being treated with hemodialysis for chronic renal failure overcome suffering. The survival rate at 5 years of this population is $40 \%$. In this population, $34.6 \%$ had diabetes and $34.9 \%$ have heart disease, which significantly increase the risk of eventually become, for example, in a patient with renal cardiac critical care.

One of the recurring issues in these hemodialysis patients constitute travel from their villages to the cities where there hemodialysis service. The tour, periodically repeated, is itself the source of sensations and perceptions that lead to various family and employment difficulties in daily life. The search for flats near the cities where there hemodialysis machines, the impact the disease has on individuals and their families have been exposed in several works by Frank [38]-[40]. However, little is known about how people talk about these liminal experiences (right at the threshold of consciousness) that are sometimes beyond words and are complicated when externalize. This subliminal context fraught with uncertainty, is where the narrative materials reveal their potential to transmit both the facts (the behaviors, the obvious), such as feelings, beliefs, values that are affecting, at a given moment, the experiences of the patient or critical care nephrology. Francisco Herrera [71] on "Diseases of Sisyphus" described and demonstrated by accurate examples, the utility of narrative as a vehicle to understand the situations in which different types of diseases that are suffered by people who stubbornly remain so are a despite the stigma that has befallen them. Also the work of Gracia Armendáriz "Diary of a pale man" establishing an interesting comparative analysis with experienced authors who have racked their meat and their works the pain of the disease and/or the loss of a loved one being particularly significant allusion to Francisco Umbral and "Mortal y Rosa" [70]. Gracia Armendáriz, in his diary covering one hundred sixty-nine days recounting a process during which the protagonist is compelled to completely change their lifestyles, quit his job, accompanied by severe dieting take no less strong drugs. All this waiting for one hope: the transplant. Gracia Armendáriz [47] and Herrera [71] (to remind us of the process that went through his father) remind us of the existential characteristic landscape commas uremic produce stupor, disorientation and memory loss. Regarding the cult of technology prevailing at home in health centers, the author claims the humanization of care by way of empathy and patient - health professional interaction:

"A paranoid Phantasmagoria: are not machines that purify the blood of patients, but we, the pa-tients, who serve machines because without the support of our blood, with high levels of phosphorus and potassium, they cease instantly and the hidden and shameful gear they serve crumble, and with it all the health institution" [47] (Gracia Armendáriz, 2010: 143). "every physician should be subjected to the same treatments he administered to their patients" [47] (Gracia Armendáriz, 2010: 44). In relation to the concept of person, which remains despite all the sick, Gracia Armendáriz noted in relation to continue feeling that a person, not just a disease and demanding, therefore care that exceeded the boundaries of pathology to achieve the whole person:"Someone has a duty to remember the obvious" confirming reflections Hurley [55] and Barthes [56] on this issue. 


\subsubsection{Narrative and Critical Cares}

In critical care we find autobiographical works in which, as in nephrology patients are holistically reflect the experiences of people who, despite their diagnosis status, they still have knowledge, history, beliefs, feelings, traditions, culture, etcetera. This is the case of José Comas, who being diagnosed with lymphoma, writes in a blog their experiences and send them to your friends. José Comas [46] written between December 2004 and February 2008, a day in which he describes his experiences as a person, journalist correspondent of the "Country" in Germany and lymphoma diagnosed "non-Hodgkin" at age 60. Try by all means to be an observer of himself, of his illness and tries to do so without losing the sarcasm and sense of humor: "I am a spectator of my own evil and I hope to maintain this position as far as necessary," but also echoes not particularly hopeful moments:"If everything goes wrong, I'll have to instruct the 'piper' to touch 'Asturias beloved country' and I prostitues to Sella" although even for the worst cases death, try to keep the ironic tone that characterized him:"the bone marrow transplant Stefan Morsch, who suffered from leukemia, was a success. The patient died of pneumonia" [46]. Marta Allué [41] [42], after an accident that nearly cost him his life and that gave significant sequelae in the form of burns, wrote about his experiences in "Losing l" and his work "Surviving in the ICU". The author makes an effort and try to recall over each time after his return to the perceptual activity when regains consciousness in an almost inhumane conditions: rescues of ostracism from the world of dreams those nightmares that alternated with episodes in which the hallucinations did nothing but increase the physical suffering caused by all kinds of processes which had to undergo during the cures. Later, tells the hard reality of the rehabilitation process. We talk about your values, your beliefs, but most of all, your feelings and your mood swings in which alternating phases too quickly for some hope with uncertainty and downright depressing vital reluctantly. The book begins with the same story of the time of the accident, and from here tells us his experience with the disease, the common thread being their way through various health institutions. From his time in the service of semi-consciousness ICU, in which memories are clouded and confused, until the "recovery" of their autonomy, to multiple surgical procedures (some of them in the US). History is not just a succession of events, but also the feelings and impressions of the author. Throughout the whole work, Marta Allué talks about her experiences in the patient role which is stripped of its status as a person. Ramón Sampedro (1996) wrote his "Letters from Hell" in a poetic prose in which he signified the pain he felt after being at twenty-five quadriplegic after an accident after jumping into the sea from the top of a rock. Rage, suffering, death wish. As a result of that sentimental corollary Sampedro in his attempt to convey the pain that burns his soul to the nurses leave comes as shocking and disturbing testimonies like this: "Guardians of complex dreams, all broken. Careers of eternal anguish with sacred fires. You, that you keep the miserable lives of agonizing bodies. Vestal that you keep the fire burning in this hell. Samaritans of balsamic smiles that give pain. Sensitive spirits contemplate smiling despair. Unknowingly you cease to hear the screams of the damned (...)." [43]. Almost all of the authors cited agree on one fact: qualitative research in general and employing sources, methods and narrative techniques in particular, have among their principles generalizing results. Nor, of course, the standardization of treatment based on the results. Consider this factor, especially when you consider the enormous variability of existential meanings and responses that lead to the experiences in critical care situations and/or nephrology. This variability may be due in large part to the diversity of belief, culture, values, family, social and work environment, etc., but above all, we must not forget, when it comes to people, each of them can be a world than to know. Consequently not all follow the same pattern or path, although you can set key points that are shared by the majority. Subjectivity is a source that works dialectic, in the sense that although conveys meanings that experiences have for people (accompanied by feelings, beliefs, values, etc..); however, does not provide clear-cut solutions for technical problems, procedural, etc. Therefore require further studies combining qualitative subjectivity is considered and valued, with quantitative research that the other dimensions of reality involved in care also have their place. In critical care combining narratives provided by the authors retrospectively (Allué, Sampedro, Grace Armendáriz, Comas, etc.), gives us an insight into the different experiences regarding the narratives collected "ad hoc" at the same time hemodialysis or interview relatives while their relatives are admitted to the ICU. While in the second, narratives diachronic lack that, in the first case a temporary overview where the longitudinal plane is present is provided. In nephrology care is much more common to find synchronous narratives in which the experience is transmitted in key this time.

\subsection{The Narrative as a Source of Knowledge in Renal Care}

Narrative materials describing the experiences of people living in nephrology or critical care are a source of 
knowledge from the principles of the hermeneutic and socio-critical paradigm, qualitative research methods and biographical and autobiographical narrative techniques. In short, this type of sources, theories and methods relevant for:

a) The descriptive study that reflected the facts, meanings and feelings on the part of that has lived, facilitating the understanding of the phenomenon holistically.

b) Tools that can contribute to the awareness of the new realities in which people and their environments (family, social and professional) in critical care situations or are nephrology. And consequently, enhance socialization of these people and their organization in groups and associations involved in improving their living conditions.

\subsubsection{Narrative and Renal Cares}

In any chronic condition affecting the body changes occur, but also the language to what is happening. Metaphors creatively to not bottom are used, often painful issue through metaphors, especially in situations such as cancer or AIDS, but metaphors are also used to refer to hemodialysis and ICU Sontag and Conelly and Clanding [54] [60] identified the three essential components of narrative inquiry: the person and time (time being and heideggerian), sociability, and space. In his view, the understanding of the people who are in these situations, build their reinterpretations of their new realities and problems considering primarily through personal time, social conditions, and the contexts in which the experiences take place. All this is essential for the design and analysis of rigorous narrative inquiry [35].

Kierans and Maynooth [69] explore the experiences of patients with chronic renal failure in the final state. They use in-depth interviews (77 cases) and 12 life histories applied as a source of data collection in hemodialysis units from different cities in Ireland. They found the cultural exchange of experiences from a natural event that affects the physiology of individuals. From the daily di-agnostic needs are considered just or even trivialize as eating, drinking, urinating, having sex, social or labor participation and actions are not part of a response to everyday life. Now, in the new situation of dependence on the hemodialysis machine new ratings and sensations that affect the reinterpretation of the ranking values and priorities of the patient who needs to reinvent itself with a new self-image, an image that also has cultural components arise and social impact on one or sandwiched always linked with hemodialysis family, social and work experience. After a hemodialysis patient recounts how angry he was with his family when he returned home: “(...) I could hear the bubbling. I never imagined it would be this bad experience. When the anesthetic disappeared, the pain was terrible. Mentally I found most disturbing, I thought I had reached the end (...)" [69] (Kierans and Maynooth, 2001: 244). In general prevailing feeling of dependence on the hemodialysis machine and fistula nuclear occupies a place in the experiences of patients, because depending on how it evolves, adapting to family, social and professional life is more or less.

Anita E. Molzahn, Laurene Sheilds Anne and Bruce (2008) in her work: "Learning from stories of People with chronic kidney disease", study the panorama of patients who were being treated with hemodialysis Participants in this study were those who had the history of the heroes of the book: 100 stories of experiences with renal insufficiency (DTU, 2000). All were receiving treatment in Units Dialysis and Transplantation, Royal Victoria Hospital, McGill University Health Center in Montreal. The book includes stories of 100 people (62 men and 38 women). Their ages ranged from 21 to 88 years, and cover a wide range of treatment modalities and a wide range in the length of experience with the treatments.

In Canada, in 2004, 18,827 people in Canada were being treated with hemodialysis for chronic renal failure overcome suffering. The survival rate at 5 years of this population is $40 \%$. In this population, $34.6 \%$ had diabetes and $34.9 \%$ have heart disease, which significantly increase the risk of eventually become, for example, in a patient with renal cardiac critical care.

One of the recurring issues in these hemodialysis patients constitute travel from their villages to the cities where there hemodialysis service. The tour, periodically repeated, is itself the source of sensations and perceptions that lead to various family and employment difficulties in daily life. The search for flats near the cities where there hemodialysis machines, the impact the disease has on individuals and their families have been exposed in several works by Frank [38] [40]. However, little is known about how people talk about these liminal experiences (right at the threshold of consciousness) that are sometimes beyond words and are complicated when externalize. This subliminal context fraught with uncertainty, is where the narrative materials reveal their potential to transmit both the facts (the behaviors, the obvious), such as feelings, beliefs, values that are affecting, at a given moment, the experiences of the patient or critical care nephrology. 
Francisco Herrera [71] on "Diseases of Sisyphus" described and demonstrated by accurate examples, the utility of narrative as a vehicle to understand the situations in which different types of diseases that are suffered by people who stubbornly remain so are a despite the stigma that has befallen them. Also the work of Gracia Armendáriz "Diary of a pale man" establishing an interesting comparative analysis with experienced authors who have racked their meat and their works the pain of the disease and/or the loss of a loved one being particularly significant allusion to Francisco Umbral and "Mortal y Rosa" [70]. Gracia Armendáriz, in his diary covering one hundred sixty-nine days recounting a process during which the protagonist is compelled to completely change their lifestyles, quit his job, accompanied by severe dieting take no less strong drugs. All this waiting for one hope: the transplant. Gracia Armendáriz [47] and Herrera [71] (to remind us of the process that went through his father) remind us of the existential characteristic landscape commas uremic produce stupor, disorientation and memory loss. Regarding the cult of technology prevailing at home in health centers, the author claims the humanization of care by way of empathy and patient-health professional interaction:

"A paranoid Phantasmagoria: are not machines that purify the blood of patients, but we, the patients, who serve machines because without the support of our blood, with high levels of phosphorus and potassium, they cease instantly and the hidden and shameful gear they serve crumble, and with it all the health institution" [47] (Gracia Armendáriz, 2010: 143). "Every physician should be subjected to the same treatments he administered to their patients" [47] (Gracia Armendáriz, 2010: 44). In relation to the concept of person, which remains despite all the sick, Gracia Armendáriz noted in relation to continue feeling that a person, not just a disease and demanding, therefore care that exceeded the boundaries of pathology to achieve the whole person: "Someone has a duty to remember the obvious" confirming reflections Hurley [55] and Barthes [56] on this issue.

\subsubsection{Narrative and Critical Cares}

In critical care we find autobiographical works in which, as in nephrology patients are holistically reflect the experiences of people who, despite their diagnosis status, they still have knowledge, history, beliefs, feelings, traditions, culture, etcetera. This is the case of José Comas, who being diagnosed with lymphoma, writes in a blog their experiences and send them to your friends. José Comas [46] written between December 2004 and February 2008, a day in which he describes his experiences as a person, journalist correspondent of the "Country" in Germany and lymphoma diagnosed "non-Hodgkin" at age 60. Try by all means to be an observer of himself, of his illness and tries to do so without losing the sarcasm and sense of humor: "I am a spectator of my own evil and I hope to maintain this position as far as necessary," but also echoes not particularly hopeful moments: "If everything goes wrong, I'll have to instruct the 'piper' to touch 'Asturias beloved country' and I prostitues to Sella" although even for the worst cases death, try to keep the ironic tone that characterized him: "the bone marrow transplant Stefan Morsch, who suffered from leukemia, was a success. The patient died of pneumonia" [46]. Marta Allué [41]-[42], after an accident that nearly cost him his life and that gave significant squeal in the form of burns, wrote about his experiences in "Losing l" and his work "Surviving in the ICU". The author makes an effort and try to recall over each time after his return to the perceptual activity when regains consciousness in an almost inhumane conditions: rescues of ostracism from the world of dreams those nightmares that alternated with episodes in which the hallucinations did nothing but increase the physical suffering caused by all kinds of processes which had to undergo during the cures. Later, tells the hard reality of the rehabilitation process. We talk about your values, your beliefs, but most of all, your feelings and your mood swings in which alternating phases too quickly for some hope with uncertainty and downright depressing vital reluctantly. The book begins with the same story of the time of the accident, and from here tells us his experience with the disease, the common thread being their way through various health institutions. From his time in the service of semi-consciousness ICU, in which memories are clouded and confused, until the "recovery" of their autonomy, to multiple surgical procedures (some of them in the U.S.). History is not just a succession of events, but also the feelings and impressions of the author. Throughout the whole work, Marta Allué talks about her experiences in the patient role which is stripped of its status as a person. Ramón Sampedro (1996) wrote his "Letters from Hell" in a poetic prose in which he signified the pain he felt after being at twenty-five quadriplegic after an accident after jumping into the sea from the top of a rock. Rage, suffering, death wish. As a result of that sentimental corollary Sampedro in his attempt to convey the pain that burns his soul to the nurses leave comes as shocking and disturbing testimonies like this: "Guardians of complex dreams, all broken. Careers of eternal anguish with sacred fires. You, that you keep the miserable lives of agonizing bodies. Vestal that you keep the fire burning in this hell. Samaritans of balsamic smiles that give pain. Sensitive spirits contemplate smiling despair. Unkno- 
wingly you cease to hear the screams of the damned (...)." [43].

Almost all of the authors cited agree on one fact: qualitative research in general and employing sources, methods and narrative techniques in particular, have among their principles generalizing results. Nor, of course, the standardization of treatment based on the results. Consider this factor, especially when you consider the enormous variability of existential meanings and responses that lead to the experiences in critical care situations and/or nephrology. This variability may be due in large part to the diversity of belief, culture, values, family, social and work environment, etc., but above all, we must not forget, when it comes to people, each of them can be a world than to know. Consequently not all follow the same pattern or path, although you can set key points that are shared by the majority. Subjectivity is a source that works dialectic, in the sense that although conveys meanings that experiences have for people (accompanied by feelings, beliefs, values, etc..); however, does not provide clear-cut solutions for technical problems, procedural, etc. Therefore require further studies combining qualitative subjectivity is considered and valued, with quantitative research that the other dimensions of reality involved in care also have their place. In critical care combining narratives provided by the authors retrospectively (Allué, Sampedro, Grace Armendáriz, Comas, etc.), gives us an insight into the different experiences regarding the narratives collected "ad hoc" at the same time hemodialysis or interview relatives while their relatives are admitted to the ICU. While in the second, narratives diachronic lack that, in the first case a temporary overview where the longitudinal plane is present is provided. In nephrology care is much more common to find synchronous narratives in which the experience is transmitted in key this time.

\section{Conclusions}

The relevance of qualitative research in the context of critical care and nephrology lies in its potential to clarify the meanings that experiences have for patients.

The study of the narrative sources identifies the incidence of experiences, feelings, beliefs and values in renal and critical care. It also promotes the humanistic perspective on this kind of care.

Pre-epistemological clarification, by reflecting on the paradigmatic location and consistent adoption of theories, methods and techniques in qualitative research is essential to the relevance and effectiveness of critical and renal cares. The narrative qualitative research materials are suitable for the study of experiences, meanings, feelings and ultimately, to maintain a holistic view of critical care and nephrology.

In this study we have identified three cultural moments: multicultural, intercultural and transcultural. These phases are loaded with symbolism and ritual components they involve social changes for the sake of community integration of kidney patients. Liminal moments occur especially in the multicultural moment due to the lack of communication between the pre-diagnostic and post-diagnostic phase, with the individual unable to reinterpret their new situation.

The preliminary step of any research must consider what kind of knowledge is sought (glob-al, partial, objective, subjective), according to the kind of knowledge to investigate some theories, methods and techniques adopted in the context of a particular scientific paradigm.

\section{References}

[1] Denzin, N. and Lincoln, Y. (2000) Handbook of Qualitative Research. Sage, Thousand Oaks.

[2] Denzin, N. (2001) Interpretive Interactionism. Sage, Thousand Oaks.

[3] Taylor, S.J. and Bogdan, R. (2012) Introducción a los métodos cualitativos de investigación. Paidós, Barcleona.

[4] Goetz, J.P. and Lecompte, M.D. (1988) Etnografía y diseño cualitativo en investigación educativa. Morata, Madrid.

[5] Szent-Györgyi, A. (1980) Dionysians and Apollonians. In: Key, M.R., Ed., The Relationship of Verbal and Non Verbal Communication, Mouton, New York, 317-318.

[6] Siles González, J. (1997) Epistemología y enfermería: por una fundamentación científica y profesional de la disciplina. Enfermería Clínica, 7, 188-194.

[7] López Parra, H.J. (2001) Investigación cualitativa y participativa un enfoque histórico-hermenéutico y crítico-social en psicología y educación ambiental. Escuela de Ciencias Sociales. Facultad: Facultad de Psicología Universidad Pontificia Bolivariana, Medellín.

[8] Siles González, J., Solano Ruiz, C. and Cibanal, L. (2005) Holismo e investigación cualitativa en el marco de la antropología de la complejidad: una reflexión sobre la pertinencia metodológica en ciencias sociosanitarias y humanas. Cultura de los Cuidados, 9, 68-81. 
[9] Siles González, J. and García, E. (1995) Las características de los paradigmas y su adecuación a la investigación en enfermería. Enfermería Científica, 160/161, 10-15.

[10] Sacks, O. (2006) Un antropólogo en marte. Anagrama, Madrid.

[11] Sacks, O. (2004) El hombre que confundió a su mujer con un sombrero. Anagrama, Madrid.

[12] Sacks, O. (2009) Musicofilia. Anagrama, Madrid.

[13] Merleau Ponty, M. (1985) Fenomenología de la percepción. Planeta Agostini, Barcelona.

[14] Bernat, R., López, J. and Fontseca, J. (2000) Vivencias de los familiares del enfermo ingresado en la unidad de cuidados intensivos. Un estudio cualitativo. Enferm Clin. 10/1:10:19

[15] Jamerson, P.A., et al. (1996) The Experience of Families with a Relative in the Intensive Care Unit. Heart Lung, 25, 467-474. http://dx.doi.org/10.1016/S0147-9563(96)80049-5

[16] Wilkinson, P. (1995) A Qualitative Study to Establish a Self-Perceived Needs of Family Members of Patients in a General Intensive Care Units. Intensive and Critical Care Nursing, 11, 77-86.

[17] Eggenberger, S.K. and Nelms, T.P. (2007) Family Interviews as a Method for Family Research. Journal of Advanced Nursing, 58, 282-292. http://dx.doi.org/10.1111/j.1365-2648.2007.04238.x

[18] Escalante, M.T.U., Torres, C.M. and Ruiz, J.R. (2004) Percepción familiar del paciente crítico cardiovascular. Investigación y educación en enfermería, 22, 50-61. http://aprendeenlinea.udea.edu.co/revistas/index.php/iee/article/view/2962/2669

[19] Torres, L. and Morales, J.M. (2004) Participación familiar en el cuidado del paciente crítico. Recomendaciones de la Sociedad Andaluza de Enfermería de Cuidados Críticos. Tempos Vitalis. Revista Internacional para el Cuidado del Paciente Crítico, 4, 18-25.

[20] Henneman, E. and Cardin, S. (2002) Family-Centered Critical Care: A Practical Approach to Making It Happen. Critical Care Nurse, 22, 12-19. http://www.ihi.org/resources/Pages/Publications/Familycenteredcriticalcareapracticalapproachtomakingithappen.aspx

[21] Abizanda, R. (2007) Sobre las necesidades reales de los familiares de pacientes de cuidados intensivos: percepción de los familiares y del profesional. Medicina Intensiva, 31, 271-272.

[22] Molte, R.N.C. (1979) Needs of Relatives of Critically Ill Patient: A Descriptive Study. Heart \& Lung: The Journal of Acute and Critical Care, 8, 332-339.

[23] Maxwell, K.E., Stuenkel, D. and Saylor, C. (2007) Needs of Family Members of Critically Ill Patients: A Comparison of Nurse and Family Perceptions. Heart \& Lung: The Journal of Acute and Critical Care, 36, 367-376. http://dx.doi.org/10.1016/j.hrtlng.2007.02.005

[24] Santana, L., et al. (2007) Necesidades de los familiares de pacientes de cuidados intensivos: percepción de los familiares y del profesional. Medicina Intensiva, 31, 273-280. http://dx.doi.org/10.1016/S0210-5691(07)74826-X

[25] Pochard, F., Azoulay, E., Chevret, S., Lemaire, F., Hubert, P., Canoui, P., Grassin, M., Zittoun, R., le Gall, J.R., Dhainaut, J.F. and Schlemmer, B. (2001) Symptoms of Anxiety and Depression in Family Members of Intensive Care Unit Patients: Ethical Hypothesis Regarding Decision-Making Capacity. Critical Care Medicine, 29, 1893-1897. http://dx.doi.org/10.1097/00003246-200110000-00007

[26] Bolivar Botía, A. (2002) “¿De nobis ipsis silemus?”: Epistemología de la investigación biográfico-narrativa en educación. Revista Electrónica de Investigación Educativa, 4, 1-26. http://www.uvmnet.edu/investigacion/episteme/numero1-04/impresiones/resenas 1.asp

[27] Saltalamacchia, H. (2008) Casuística y subjetivismo: Falsos estigmas de la investigación cualitativa. Cinta de Moebio, 109-126. http://www.moebio.uchile.cl/32/\%20saltalamacchia.htm

[28] Gaydos, H.L. (2005) Understanding Personal Narratives: An Approach to Practice. Journal of Advanced Nursing, 49, 254-259. http://dx.doi.org/10.1111/j.1365-2648.2004.03284.x

[29] Bruner, J. (1991) The Narrative Construction of Reality. Critical Inquiry, 18, 1-21.

[30] González, J.S., Sánchez, P.F., Cañaveras, R.M.P. and Hernández, E.G. (1993) Las alteraciones en la vida cotidiana de los enfermos terminales a través del análisis de textos: Un modelo simulado para las prácticas con el proceso de enfermería. Enfermería Cientifica, 4-9.

[31] González, J.S., Bravo, E.M.G., Tolino, D.M., Frías, Y.G. and Hernández, E.G. (1997) Por una rentabilización pedagógica en la obra de Benedetti: Etnología narrativa y situaciones de vida-salud. Cultura de los Cuidados, 1, 17-24. http://rua.ua.es/dspace/bitstream/10045/5309/1/CC 01 04.pdf

[32] Siles González, J. (2000) Antropología narrativa de los cuidados. CECOVA, Alicante.

[33] Clandinin, D.J. (2006) Handbook of Narrative Inquiry: Mapping a Methodology. Sage, Thousand Oaks.

[34] Clandinin, D.J. and Connelly, F.M. (2000) Narrative Inquiry: Experience and Story in Qualitative Research. Jossey- 
Bass, San Francisco

[35] Clandinin, D.J., Pushor, D. and Orr, A.M. (2007) Navigating Sites for Narrative Inquiry. Journal of Teacher Education, 58, 21-35. http://dx.doi.org/10.1177/0022487106296218

[36] Garro, L. (1994) Narrative Representations on Chronic Illness Experience. Social Science and Medicine, 38, $775-788$. http://www.sciencedirect.com/science/article/pii/0277953694901503

[37] Connelly, F.M. and Clandinin, D.J. (2006) Narrative Inquiry: A Methodology for Studying Lived Experience. Research Studies in Music Education, 27, 44-54. http://dx.doi.org/10.1177/1321103X060270010301

[38] Frank, A.W. (1995) The Wounded Storyteller. University of Chicago Press, Chicago. http://dx.doi.org/10.7208/chicago/9780226260037.001.0001

[39] Frank, A.W. (2001) Can We Research Suffering? Qualitative Health Research, 11, 353-362. http://dx.doi.org/10.1177/104973201129119154

[40] Frank, A.W. (2002) Why Study People's Stories? The Dialogical Ethics of Narrative Analysis. International Journal of Qualitative Methods, 1. http://www.ualberta.ca/ iiqm/backissues/1_1Final/pdf/frankeng.pdf

[41] Allué, M. (1996) Perder la piel. Seix Barral, Barcelona.

[42] Allué, M. (1997) Sobrevivir en la UCI. Enfermería Intensiva, 6, 29-34.

[43] Sampedro, R. (1996) Cartas desde el infierno. Planeta Barcelona.

[44] Gilbert, H. (1992) El protocolo compasivo. Tusquets, Barcelona.

[45] Zorn, F. (1991) Bajo el signo de Marte. Anagrama, Madrid.

[46] Comas, J. (2009) Crónicas del linfoma. Rey Lear, Madrid.

[47] Armendáriz, J.G. (2010) Diario del hombre pálido. Demipage, Madrid.

[48] Sacks, O. (2010) Despertares. Anagrama, Madrid.

[49] Siles, J. and Solano, C. (2009) Antropología educative de los cuidados. Una etnografia del aula y las prácticas clínicas. ICE, Universidad de Alicante, Alcoy, Alicante. http://rua.ua.es/dspace/handle/10045/20339

[50] Van Gennep, A. (2013) Los ritos de paso. Alianza, Madrid.

[51] Turner, V. (1990) Liminality and Community. In: Alexander, J.C. and Seidman, S., Eds., Culture and Society: Contemporary Debates, Cambridge University, Cambridge, 147-154.

[52] Turner, V. (2008) The Ritual Process: Structure and Anti-Structure. Transaction Publishers, Piscataway.

[53] Gergen, K. (2001) Social Construction in Context. Thousand. Sage, Thousand Oaks.

[54] Salkalys, J.A. (2003) Restoring the Patient's Voice. Journal of Holistic Nursing, 21, 228-241. http://dx.doi.org/10.1177/0898010103256204

[55] Hurley, R.E. (1999) La investigación cualitativa y el profundo entendimiento de lo obvio. Health Services Research, 34, 1119-1136.

[56] Benner, P. (1991) The Role of Narrative Experience and Community in Skilled Ethical Comportment. Advances In Nursing Science, 14, 1-21. http://dx.doi.org/10.1097/00012272-199112000-00003

[57] Sacks, O. (2013) Alucinaciones. Anagrama, Madrid.

[58] Gombrowicz, W. (1983) Ferdydurke. Sudamericana, Buenos Aires.

[59] Sontag, S. (1985) La enfermedad y sus metáforas. Muchnik Editores, Barcelona.

[60] Entralgo, P.L. (1986) Antropología médica para clínicos. Salvat, Barcelona.

[61] Allport, G. (1985) La personalidad: su configuracion y desarrollo. Herder, Madrid

[62] Morin, E. (1994) Introduccion al pensamiento complejo. Gedisa, Barcelona.

[63] Medina, J.L. and Sandin, M.P. (1995) Epistemología y Enfermería: Paradigmas de la investigación en Enfermería. Enfermería Clínica, 5, 32-44.

[64] Arricivita, A., Cabrera, J., Arias, M., Robayna, M.C. and Díaz, L. (2002) Características de la organización de las visitas en las unidades de cuidados críticos de la Comunidad Autónoma de Canarias. Enfermería en cardiología: Revista científica e informativa de la Asociación Española de Enfermería en Cardiología, 36-40.

[65] Padfield, A. (1976) Letter: Music as Sedation for Local Analgesia. Anesthesia, 31, 300-301. http://dx.doi.org/10.1111/j.1365-2044.1976.tb11819.x

[66] Peretz, I. (2001) Listen to the Brain. A Biological Perspective on Musical Emotions. In: Juslin, P. and Sloboda, J., Eds., Music and Emotion: Theory and Research, Oxford University Press, New York, 105-134.

[67] Diaz, R. (2006) Régimen de visitas en la unidad coronaria y su influencia en el pronóstico. Revista electrónica de Me- 
dicina Intensiva (REMI), 6. http://remi.uninet.edu/2006/03/REMI0964.htm

[68] Margall, M.A. and Asiain, M.C. (2000) Creencias y actitudes de las enfermeras de cuidados intensivos sobre el efecto que la visita abierta produce en el paciente, familia y enfermeras. Enfermería Intensiva, 11, 107-117.

[69] Kierans, C.M. and Maynooth, N.U.I. (2001) Sensory and Narrative Identity: The Narration of Illness Process among Chronic Renal Sufferers in Ireland. Anthropology \& Medicine, 8, 237-253.

[70] Herrera, F. (2011) Las enfermedades de Sísifo. Imprenta Rimada, Cádiz.

[71] Herrera, F. (2011) Diario de un hombre pálido. Cultura de los Cuidados, 31, 127-141. http://rua.ua.es/dspace/bitstream/10045/20579/1/CC 31_16.pdf

\section{Acronimos}

AIDS $=$ Acquired immunodeficiency syndrome

$\mathrm{ICU}=$ Intensive Care Unit. 